\title{
水工用アスファルト混合物の低温ひび割れ 抵抗性に関する実験的研究
}

\author{
大野俊夫 $1 \cdot$ 渡部貴裕 $2 \cdot$ 万木正弘 3 \\ 1正会員 博(工) 鹿島建設株式会社 技術研究所（ \\ E-mail:ohno-t@kajima.com \\ 2 正会員 工修 鹿島建設株式会社 九州支店（广884-0104 宮崎県児湯郡木城町大字石河内1222） \\ ${ }^{3}$ 正会員 博(工) 弘前大学 農学生命科学部（T036-8561 青森県弘前市文京町3）
}

\begin{abstract}
水工用アスファルト混合物の低温ひび割れ抵抗性を評価する研究の一環として, リング状の拘束体の外 周にアスファルト混合物を打設，転圧した供試体を低温環境下に曝してひび割れを発生させ，アスファル 卜混合物の材料・配合条件，拘束条件，温度履歴条件などがひび割れ発生温度に及ほす影響を把握すると ともに，ひび割れ発生時にアスファルト混合物に作用しているひずみや応力，粘弾性体から弾性体に移行 する転移点温度について検討を行った．また，アコースティックエミッションの測定によりアスファルト 混合物に微細ひび割れの発生が開始される温度を把握し, 転移点温度や貫通ひび割れ発生温度との関係, 微細ひび割れの発生メカニズムなどを示した。
\end{abstract}

Key Words : asphalt mixture, cracking resistance at low temperature, critical limit, thermal fatigue, transition point

\section{1.はじめに}

アスファルト混合物は高い遮水性，変形追従性，耐久 性を有することから，フイルダムや貯水池などの表面遮 水壁に採用されてきている1). しかしながら，寒冷地や 標高の高い地点にアスファルト表面遮水壁の建設が予定 される場合, 線膨張係数がコンクリートなどに比較して 大きいことから, 常温から低温に移行する過程での収縮 量が大きくなる。また，極低温下では脆性的な挙動を示 す材料であることから，この収縮が何らかによって拘束 された場合にはひび割れが発生し, 遮水機能が確保でき なくなることが懸念される，このため，温度収縮に対す るひび割れ抵抗性について，事前に照査する必要があり， アスファルト混合物のひび割れ発生温度あるいは破壊時 の応力やひずみなどの破壊限界点を把握することが重要 な課題とされている.

この温度応力ひび割れに関する研究は，これまで多く の研究者によって行われてきており, 発生する温度応力 の程度 ${ }^{2}$ ，ひび割れ発生温度や応力緩和限界温度に及ぼ すアスファルトの種類や配合の影響3;4, 解析的に温度応 力を求める方法2)のなどが報告されている. 近年, アメリ カの高速道路に関する戦略的研究プログラム (SHRP) において，長期供用後の低温ひび割れ性とベンディング
レオメータ試験やインダイレクトテンション試験の結果 とが関連付けられており, 使用予定地域の最低温度から 使用可能なアスファルトのグレードを選定することがな されている゚. しかしながら, 遮水壁などを対象とした 水工用アスファルト混合物に対する実験や実構造物にお ける報告事例が少ないのが現状である。

直接, ひび割れの発生の有無によって低温ひび割れ抵 抗性を評価する方法としては, アスファルト自身に対し てフラース脆化点試験や森吉脆化点試験があり, 各脆化 点の相関関係やアスファルト混合物の破壞温度との関係 について実験的研究がなされてきているク,8. アアスファル 卜混合物を対象とした試験方法としては直方体の供試体 を用いて両端を固定する方法2)33，内側に拘束体を有す るリング状供試体を用いた方法9などがある。しかしな がら, 直方体の供試体の場合には拘束体に固定する部位 周辺の応力集中により比較的小さい応力で破壊するなど の問題から，特殊な治具などが必要となり ${ }^{10)}$, また，リ ング状供試体は流し込み可能な混合物を対象とした試験 であった9".

筆者らは，リング状の拘束体の外周にアスファルト混 合物を打設し，特殊な治具を用いて転圧することによっ て供試体を作製する方法を開発し，この供試体を冷媒中 で温度低下させ，拘束体とアスファルト混合物の線膨張 


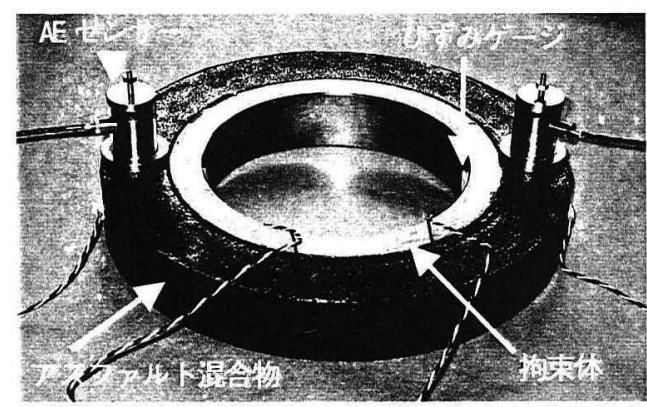

写真一1 低温ひび割れ抵抗性試験用供試体

係数の違いからアスファルト混合物の自由収縮を拘束し, ひび割れを発生させる試験を行ってきている ${ }^{11) ~ 14) . ~}$

本研究は，この低温ひび割れ抵抗性試験方法を採用し， 材料・配合条件，拘束条件や温度条件を実験要因として, アスファルト混合物に貫通ひび割れが発生した温度を測 定するとともに，ひび割れ発生時のひずみや引張応力， 粘弾性体から弾性体に移行する転移点温度の検討を行う とともに，アコースティックエミッションの測定によっ てアスファルト混合物内に発生する微細ひび割れの発生 開始温度，メカニズムなどを総合的に検討したものであ る.

\section{2. 低温ひび割れ抵抗性試験方法}

\section{（1）供試体の形状寸法}

供試体の形状は写真一1に示すとおりであり，コンク リートの乾燥収縮ひび割れ抵抗性試験をアスファルト混 合物に応用したものである ${ }^{15}$. 最大寸法 $13 \mathrm{~mm} の$ 骨材を 用いたアスファルト混合物を試験对象とすることから， 供試体の断面は40×40mmを基本とした．内側に配置す る拘束体の外径は $200 \mathrm{~mm}$ 一定で, 高さ $40 \mathrm{~mm}$ で肉厚を 20mmまたは10mmとし，アスファルト混合物に比べて線 膨張係数が1/40程度と非常に小さい鋼製（インバール製, $\left.\alpha=0.5 \times 10^{6} \%^{\circ} \mathrm{C}\right)$ とした. その外周部に，アスファルト 混合物の厚さが所定となるように型枠を設置して，打 設・転圧を行うことによって供試体を作製した。

アスファルト混合物の低温ひび割れはコンクリートに おける乾燥収縮ひび割れと同様に，拘束体と被拘束体の 剛性比 (拘束度)によって影響を受けると考えられたが, ここでは入手可能である $20 \mathrm{~mm}$ と $10 \mathrm{~mm}$ の肉厚の拘束体を 採用した。

\section{(2) 実験要因と水準}

表一1に実験要因と水準を示す．アスファルト材料の 低温ひび割れの発生に影響する要因には, アスファルト 混合物を構成する材料や配合などの内的要因と, 拘束度 や温度履歴などの外的要因があり，本研究ではこれらの 要因をシリーズ I 〜分けて試験を行った，なお，供 試体は拘束体の肉厚 $20 \mathrm{~mm}$, アスファルト混合物の厚さ 40mmを基本の拘束条件とした.

また，シリーズ I〜四実験の中の代表的なケースにお いて, 別途供試体を作製して低温に移行する過程のアコ ースティックエミッション（AE）の計測を行った。

\section{(3)使用材料及び配合}

実験対象としたアスファルトの種類と主な特性值を表 -2に示す.

ストレートアスファルトは針入度60/80，80/100， 100/120，1502000ののとした.一般に, 感温性の低い

(PIの大きい) アスファルトの方が低温ひび割れ抵抗性 に優れているとされている16. なお, アスファルトの線

表一1 実験要因と水潐

\begin{tabular}{|c|c|c|c|c|}
\hline シリーズ & 材料·配合 & & 要因 & 水準 \\
\hline \multirow{5}{*}{ I } & \multirow{5}{*}{$\begin{array}{c}\text { 基本材料·配 } \\
\text { 合から各水準 } \\
\text { のみを変更 }\end{array}$} & \multirow{5}{*}{ 材料·配合 } & アスファルト種類 & $\begin{array}{l}\text { StAs.60/80, 80/100, 100/120,150/200 } \\
\text { 改質A，改筫B，改質C }\end{array}$ \\
\hline & & & アスファルト量 & $7.2 \%, 8.2 \%, 9.2 \%$ \\
\hline & & & 骨材粒度 & 上方粒度, 中央粒度、下方粒度 \\
\hline & & & 空隙率 & $1 \%, 2 \%, 2.5 \%, 3 \%$ \\
\hline & & & 植物織維の添加量 & $0 \%, 0.3 \%$ \\
\hline \multirow[t]{2}{*}{ II } & \multirow{4}{*}{$\begin{array}{c}\text { 基本材料·配 } \\
\text { 合 }\end{array}$} & $\begin{array}{c}\text { 拘束度 } \\
\text { 泹度低下涑度 }\end{array}$ & $\begin{array}{l}\text { 拘束度(拘束体厚と供 } \\
\text { 試体厚の組合せ) }\end{array}$ & $\begin{array}{l}\text { 拘束体厚: } 10,20(\mathrm{~mm}) \\
\text { 供試体厚: } 20,40(\mathrm{~mm})\end{array}$ \\
\hline & & & 温度低下速度 & 速度: $-5,-10,-20\left({ }^{\circ} \mathrm{C} / \mathrm{hr}\right)$ \\
\hline \multirow[b]{2}{*}{ III } & & \multirow[b]{2}{*}{ 温度履歴 } & 一定温度持続 & $\begin{array}{l}\text { 温度: }-15,-20,-25,-30,-35\left({ }^{\circ} \mathrm{C}\right) \\
\text { 時間: } 5,10(\mathrm{hr})\end{array}$ \\
\hline & & & 温度繰返し & $\begin{array}{l}\text { 温度: }+10 \sim-35^{\circ} \mathrm{C} \text { (2回) } \\
\text { 温度: }-20 \sim-35^{\circ} \mathrm{C} \text { (6回) } \\
\text { 温度: }-20 \sim-35^{\circ} \mathrm{C} \text { (11回) } \\
\text { 温度:0 -25 (11回) } \\
\text { 温度:-10 -20 } 0^{\circ} \mathrm{C} \text { (11回) } \\
\text { 温度: }-10 \sim-25^{\circ} \mathrm{C} \text { (11回) }\end{array}$ \\
\hline
\end{tabular}


膨張係数は $590 \times 10^{6} \%{ }^{\circ} \mathrm{C}$ 程度である ${ }^{17}$.

改質アスファルトAはセミブローンアスファルトを混 合して低温ひび割れ抵抗性を改善したもの，改質アスフ アルトBはSBS系樹脂を添加して低温ひび割れ抵抗性を 改善したもの，改質アスファルトCは石油系配合油と粘 着付与剂樹脂を配合して針入度を150以上にしたもので ある。

6号, 7号砕石は北海道産の安山岩砕石, 細砂は北海道 産の海砂，石粉は炭酸カルシウムである。な执，一般的 な安山岩の線膨張係数は $8 \times 10^{6} /^{\circ} \mathrm{C}$ 程度である ${ }^{18}$.

アスファルト混合物の配合は表一3に示すとおりであ り，表一1中に示守基本材料・配合は，アスファルトの 種類がストレートアスファルト $80 / 100$, 骨材粒度が上方 粒度, 空隙率が $2 \%$, 植物繊維無添加の配合を示してい る. シリーズII， IIIのアスファルト混合物はこの基本 材料・配合とし, シリーズ I では基本材料・配合から, 対象とする要因と水準のみを変更したアスファルト混 合物としている．アスファルト量は $8.2 \%$ で，通常の道 路舗装に比べてアスファルト量が多い水工用のアスフ アルト混合物である.

\section{(4)測定項目及び計測ひずみの処理}

拘束体の内側及びアスファルト混合物の外側に低温型 のひずみゲージ $\left(-196 \sim+80^{\circ} \mathrm{C}\right.$, ゲージ長：拘束体用 $3 \mathrm{~mm}$ ，アスファルト混合物用 $30 \mathrm{~mm}$ ）を4枚ずつ貼付し (円周方向各2枚, 軸方向各2枚)，温度低下開始時から ひずみを測定した．また，水槽内の温度は熱電対により 5箇所で測定した。なお，貫通ひび割れの発生は拘束体 に貼付したひずみゲージのひずみが 0 付近に戻ることに より検知した。この貫通ひび割れ発生時のひずみの変化 は，4ヶ所のひずみゲージでほほ同一時点で検知され， 全ての実験ケースで同様な傾向が認められた。

リング拘束供試体に貼付したひずみゲージの出力値に は，アスファルト混合物及び拘束体の自由ひずみが拘束 されることによって発生するひずみのほか，ゲージの温 度特性が含まれているため，応力に関与する有効ひずみ は, 出力值から同一のひずみゲージにより測定した棒状 の自由試験体のひずみを差し引いて求めた.

\section{（5）供試体の作製方法}

リング拘束供試体の作製方法は，鋼製の拘束体と外周 部の型枠との間にアスファルト混合物を，転圧終了時に 所定の密度が確保できる重量たけ量りとって充てんし， アスファルト混合物の上にリング状の転压用治具を置き， この上からタンパを用いてアスファルト混合物にニーデ イング作用を加えながら所定の高さになるまで転圧して 作製した。

アスファルト混合物は練上り温度が $165^{\circ} \mathrm{C}$ になるう
表一2 アスファルトの種類と特性値

\begin{tabular}{|l|c|c|c|c|}
\hline \multicolumn{2}{|c|}{ 種 類 } & $\begin{array}{c}\text { 軟化点 } \\
\left({ }^{\circ} \mathrm{C}\right)\end{array}$ & $\begin{array}{c}\text { 針入度 } \\
(1 / 10 \mathrm{~mm})\end{array}$ & $\begin{array}{c}\text { 針入度指 } \\
\text { 数 (PI) }\end{array}$ \\
\hline \multirow{3}{*}{$\begin{array}{l}\text { ストレートアス } \\
\text { ファルト }\end{array}$} & $60 / 80$ & 47.5 & 70 & -1 \\
\cline { 2 - 5 } & $80 / 100$ & 45 & 88 & -1.1 \\
\cline { 2 - 5 } & $100 / 120$ & 44 & 112 & -0.7 \\
\cline { 2 - 5 } & $150 / 200$ & 38.5 & 192 & -0.9 \\
\hline \multirow{2}{*}{$\begin{array}{l}\text { 改質アス } \\
\text { フルト }\end{array}$} & $\mathrm{A}$ & 58 & 64 & 1.3 \\
\cline { 2 - 5 } & $\mathrm{B}$ & 87.4 & 99 & 7.4 \\
\cline { 2 - 5 } & $\mathrm{C}$ & 64.5 & 221 & 7.6 \\
\hline
\end{tabular}

表一3 配合

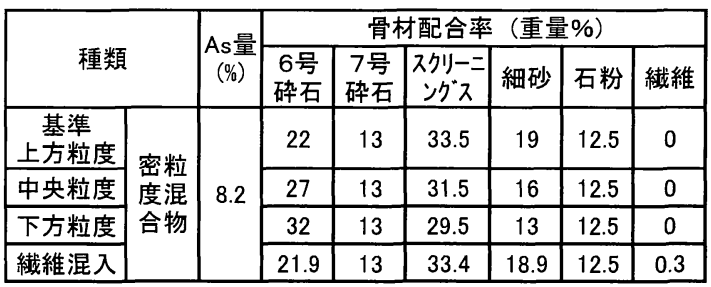

に加温しながら練混ぜた。なお，供試体作製中にアスフ アルト混合物の温度が低下して転圧不足にならないよう に, 拘束体と型枠は $165^{\circ} \mathrm{C}$ 乾燥炉の中で事前に加温し た. 上記の方法で作製した供試体中のアスファルト混合 物の密度が断面の上下や部位により差が生じないことを 事前実験によって確認した後, 本実験を行った.

作製した供試体は16時間程度常温下で静置した後，脱 型し，ひずみゲージを貼付して，ひずみゲージ部をブチ ルゴム系コーティング用テープを用いて防水した．また， ひずみゲージ部以外のアスファルト混合物にも冷媒によ る材料劣化から保護するため, 樹脂を用いてコーティン グを施した、ひずみゲージの貼付にはシアノアクリレー 卜系の常温硬化型接着剂を用い, 指圧して接着した。

低温ひび割れ抵抗性試験装置は冷却装置（温度範囲一 90 $100^{\circ} \mathrm{C}$ ) と低温水槽（内寸法： $400 \times 400 \times \mathrm{h} 240 \mathrm{~mm}$, 断熱材厚 $150 \mathrm{~mm}$ ) からなり, 冷媒がパイプを介して両者 を循環することにより，低温水槽内に静置した供試体の 温度を低下させている。

試験体数は各ケース2体を基本としたが，表一5に示す ように基本材料・配合のケース (No.2) や一部のケース では3体とした。

\section{(6)温度履歴}

低温循環槽の冷媒中に1供試体を静置し，応力開放を 行うため, $+10^{\circ} \mathrm{C} て ゙ 1$ 時間保持した後, 供試体の温度が所 定の温度低下速度になるように設定した。

図一1にアスファルト混合物に与えた温度履歴を示す。 シリーズ I と Iは温度低下速度を- $10^{\circ} \mathrm{C} / \mathrm{h}$ の一定とした。 シリーズIIIは一定温度持続と温度繰返しの2通りとした。 


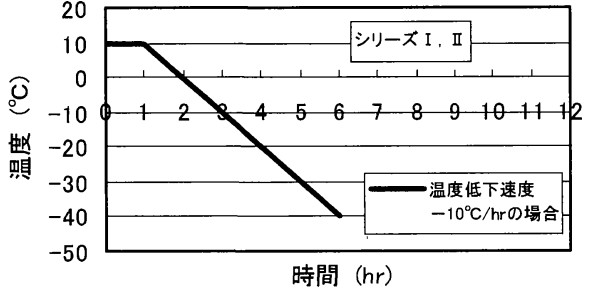

（a)図 温度低下速度一定の場合

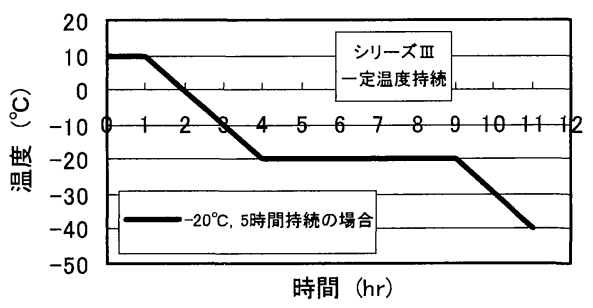

(b)図 一定温度持続の場合

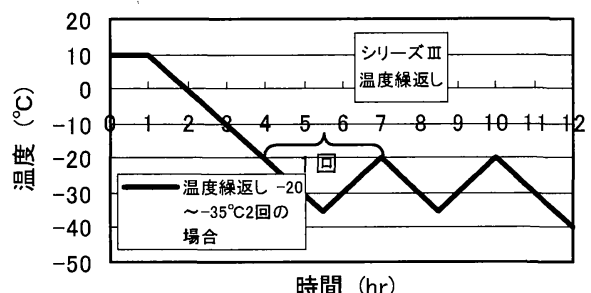

(c)図 温度繰返しの場合

図-1 温度履歴

表一4 $\mathrm{AE}$ 計測の設定值

\begin{tabular}{|c|c|c|}
\hline 項目 & 設定値 & 摘要 \\
\hline HPF(ハイパスフィルタ) & $10^{5} \mathrm{~Hz}$ & 低周波の音の上限值 \\
\hline LPF(ローパスフィルタ) & $10^{6} \mathrm{~Hz}$ & 高周波の音の下限値 \\
\hline 増幅率 & $10 \mathrm{~dB}$ & 意を增幅する \\
\hline レベル & $0.05 \mathrm{~V}$ & しきい值 \\
\hline カウント間隔 & 6分 & AE発生数のカウント間隔 \\
\hline
\end{tabular}

ここで, $-10^{\circ} \mathrm{C} / \mathrm{h}$ の温度低下速度は寒冷地の水面が上下す る調整池において，冬季に拉ける外気温の低下速度の実 測值を考慮して設定したものである．なお，冷媒の温度 と供試体の内部の温度が同程度であることを事前実験や 後述の実験によって確認している.

一定温度持続は温度低下途中で，ある一定温度に保つ 試験であり， $+10^{\circ} \mathrm{C}$ で1時間保持した後，一定速度で温度 を低下させて $\left(-10^{\circ} \mathrm{C} / \mathrm{h}\right)$ ，所定の温度に達した時点で所 定の時間（5または10時間）持続し，所定時間経過後再 び温度を低下し $\left(-10^{\circ} \mathrm{C} / \mathrm{h}\right)$ ，貫通ひび割れが発生した時 点で試験を終了した。たたし，温度持続中にひび割れの

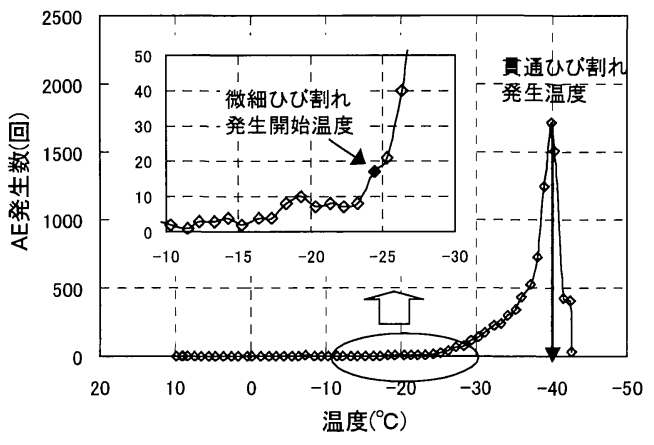

図一2 微細ひび割れ発生温度

発生を確認した場合は，その時点で試験を終了した。

温度繰返し試験は同様の手順で，温度を持続する代わ りに上限温度と下限温度間の上昇, 下降を設定回数だけ 繰り返した。

\section{3. $A E$ E計測方法}

岩石やコンクリートの破壊が進展する際にはその内部 で微細な音 (Acoustic Emission, $\mathrm{AE}$ ) が発生することが 知られており，この微細な音を計測することによって， 破壊の進行性や破壊位置の特定などの検討がなされてい $3^{19)}$.

アスファルト混合物においても貫通ひび割れに進展す る前段階の温度低下過程において, 微細な破壊が進行し て最終的に貫通ひび割れに至っているものと推察される. また，この微細な破壊，すなわち微細ひび割れの進展 が温度疲労特性に関係しているものと思われる.そこ で，この温度低下過程における微細ひび割れの進展状 況を把握するため, 低温ひび割れ抵抗性試験において $\mathrm{AE}$ 計測を行った。

$\mathrm{AE}$ 計測は装置のフィルタや増幅率の設定によってア スファルト混合物からの音と装置などからの音が混在 し，微細ひび割れの発生開始温度等の把握に誤差を含ん でしまうため，事前にこれらの設定が試験結果に及ぼす 影響を把握する予備試験を行った後, 本試験を行った.

\section{(1)実験ケース}

低温ひび割れ抵抗性試験において $\mathrm{AE}$ 計測を行った実 験ケースは表一1に示す実験ケースのうち，アスファル トの種類, 拘束度, 温度低下速度, 低温保持温度や温度 繰返しなどの影響を把握する一部の実験ケースとした。 また，微細ひび割れの発生原因を把握するため，拘束体 のないリング供試体や棒状供試体，さらにはアスファル 
ト単体やアスファルトモルタルのリング拘束供試体を作 製し，温度低下に伴う AEの計測を行った。

\section{(2) 設定値}

表一4にAE計測時の設定值を示す。フィルタや増幅率 の設定により計測されるAE数は若干異なるが, 微細ひ び割れの発生温度はこれらの設定值を同一として試験を 行うことにより把握できることが確認された． $\mathrm{AE}$ 数の カウント間隔は単位時間を6分としたが，これは1時間当 り $10^{\circ} \mathrm{C}$ 温度低下寸るケースの場合, $1^{\circ} \mathrm{C}$ 温度が低下する 時間である。

微細ひび割れの発生開始温度は温度の低下に伴って $\mathrm{AE}$ の発生が急増する温度と定義し，ノイズの存在も考 慮して同表の設定值の場合, 単位時間内にAE発生数が 10回以上カウントされ始めた温度とした（図一2参照）。

(3) センサ数

$\mathrm{AE} ン サ の$ 設置数, 位置によってAE数に若干差が認 められたが, 微細ひび割れ発生温度や貫通ひび割れ発生
温度を検知する上では差が見られなかったことから， AEセンサ数は各供試体で1個とした。

\section{4. 試験結果及び考察}

\section{(1)ひび割れ発生温度}

表一5, 図一3(a) (d)に, ひずみゲージのひずみが大き く変化したことによって把握した貫通ひび割れ発生温度 をシリーズごとに整理して示す.

ひび割れが発生したアスファルト混合物の断面は供試 体を解体する際に，冷媒によって濡れていることにより 特定できるが，全ての供試体において断面を貫通するひ び割れが1個所のみ発生していた。 また，ほとんど全て の供試体の破壊断面で粗骨材が破壊する現象が認められ た. 貫通ひび割れが粗骨材の内部を通るか，粗骨材とア スファルトの界面を通るかは, 粗骨材自身の強度と粗骨 材とアスファルトの界面の付着強度の大小に依存するが, 今回使用した安山岩系の粗骨材では粗骨材自身が破壊し

表一5 ひび割れ発生温度

\begin{tabular}{|c|c|c|c|c|c|c|c|c|c|c|c|c|c|c|c|c|c|}
\hline \multicolumn{2}{|c|}{ No. } & \multicolumn{2}{|c|}{ Asの種類 } & \multirow{2}{*}{$\begin{array}{c}\text { Ass量 } \\
(\%)\end{array}$} & \begin{tabular}{|l|} 
骨材 \\
粒度 \\
\end{tabular} & \multicolumn{2}{|c|}{\begin{tabular}{c|c} 
纖維添空弥 \\
率 \\
\end{tabular}} & $\begin{array}{l}\text { 拘束 } \\
\text { 体厚 }\end{array}$ & $\begin{array}{l}\text { As 厚 } \\
(\mathrm{mm})\end{array}$ & $\begin{array}{l}\text { 温度低 } \\
\text { 下速度 }\end{array}$ & 低温保持 & 温度繰返し & \begin{tabular}{|c|}
$\mathrm{AE}$ 計 \\
測
\end{tabular} & \multicolumn{4}{|c|}{ 貫通ひひ割れ発生温度 $\left({ }^{\circ} \mathrm{C}\right)$} \\
\hline \multirow{15}{*}{$\therefore$} & 1 & & $60 / 80$ & & \multirow{9}{*}{ 上カ } & \multirow{15}{*}{0} & \multirow{11}{*}{2} & \multirow{15}{*}{20} & \multirow{15}{*}{40} & & & & 0 & -366 & -354 & - & -360 \\
\hline & 2 & ストレー & $80 / 100$ & \multirow{6}{*}{8.2} & & & & & & & & & 0 & -37.8 & -40.0 & -38.2 & -38.7 \\
\hline & 3 & 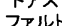 & $100 / 120$ & & & & & & & & & & 0 & -40.8 & -40.6 & - & -40.7 \\
\hline & 4 & & $150 / 200$ & & & & & & & & & & 0 & -43.7 & -42.6 & - & -43.2 \\
\hline & 5 & & $\mathrm{~A}$ & & & & & & & & & & 0 & -43.6 & -42.7 & - & -43.2 \\
\hline & 6 & 改質 & $\mathrm{B}$ & & & & & & & & & & 0 & -53.3 & -51.8 & -51.4 & -52.2 \\
\hline & 7 & & $\mathrm{C}$ & & & & & & & & & & 0 & -62.1 & -59.5 & -62.0 & -61.2 \\
\hline & 8 & & & 7.2 & & & & & & -10 & 無 & 無 & $x$ & -37.2 & -38.5 & - & -37.9 \\
\hline & 9 & & & 9.2 & & & & & & & & & $x$ & -39.5 & -38.9 & - & -39.2 \\
\hline & 10 & & & & 中央 & & & & & & & & $x$ & -39.3 & -38.2 & - & -38.8 \\
\hline & 11 & 삭ㅈ & $80 / 100$ & & 下万 & & & & & & & & $x$ & -38.0 & -38.4 & - & -38.2 \\
\hline & 12 & ファルト & $80 / 100$ & 82 & & & 1 & & & & & & $x$ & -40.0 & -40.4 & $\overline{-}$ & -40.2 \\
\hline & 13 & & & 0.2 & 上大 & & 2.5 & & & & & & $x$ & -38.7 & -37.8 & - & -38.3 \\
\hline & 14 & & & & I & & 3 & & & & & & $x$ & -37.1 & -38.9 & -37.9 & -38.0 \\
\hline & 15 & & & & & & 2 & & & & & & $x$ & -38.2 & -38.6 & - & -38.4 \\
\hline & 16 & & & & & & & 10 & 40 & & & & 0 & -42.9 & -41.4 & $=$ & -42.2 \\
\hline & 17 & & & & & & & 20 & 40 & -10 & & & - & & No.21同じ & & - \\
\hline 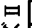 & 18 & & & & & & & & & -5 & & & $x$ & -34.7 & -35.0 & - & -34.9 \\
\hline$x$ & 19 & "I & "I & "I & "I & 0 & "I & & 20 & -10 & 無 & & 0 & -32.5 & -35.3 & - & -33.9 \\
\hline & 20 & & & & & 0 & & "I & & -20 & 膳 & & $x$ & -32.2 & -30.5 & $=$ & -31.4 \\
\hline & 21 & & & & & & & $n$ & & -5 & & & $\bar{x}$ & -39.0 & -40.3 & $=$ & -39.7 \\
\hline & 22 & & & & & & & & 40 & -10 & & & - & & No.21/同じ & & - \\
\hline & 23 & & & & & & & & & -20 & & & $\bar{x}$ & -38.7 & -37.8 & - & -38.3 \\
\hline & 24 & & & & & & & & & & $-15^{\circ} \mathrm{C}, 5 \mathrm{hr}$ & 無 & $x$ & -39.8 & -39.3 & $=$ & -39.6 \\
\hline & 25 & & & & & & & & & & 同, $10 \mathrm{hr}$ & 覀 & $x$ & -38.7 & -38.7 & - & -38.7 \\
\hline & 26 & & & & & & & & & & $-20^{\circ} \mathrm{C}, 5 \mathrm{hr}$ & & $x$ & -37.7 & -38.3 & -38.8 & -38.3 \\
\hline & 27 & & & & & & & & & & 同, $10 \mathrm{hr}$ & & 0 & -36.7 & -39.0 & -39.4 & -38.4 \\
\hline & 28 & & & & & & & & & & $-25^{\circ} \mathrm{C}, 5 \mathrm{hr}$ & & $x$ & -39.7 & -39.0 & - & -39.4 \\
\hline & 29 & & & & & & & & & & 同, $10 \mathrm{hr}$ & & $x$ & -40.0 & -38.8 & - & -39.4 \\
\hline & 30 & & & & & & & & & & $-30^{\circ} \mathrm{C}, 5 \mathrm{hr}$ & & $x$ & -38.4 & -38.7 & $=$ & -38.6 \\
\hline & 31 & & & & & & & & & & 同, $10 \mathrm{hr}$ & & $x$ & -37.6 & -39.0 & - & -38.3 \\
\hline & 32 & & & & & & & & & & $-35^{\circ} \mathrm{C}, 5 \mathrm{hr}$ & & $x$ & -36.5 & -37.9 & $=$ & -37.2 \\
\hline 男 & 33 & & & & & & & & & & 同, $10 \mathrm{hr}$ & & $\mathrm{O}$ & -35.2 & -34.9 & - & -35.1 \\
\hline $\begin{array}{l}1 \\
1 \\
1\end{array}$ & 34 & " & " & " & " & " & " & " & " & -10 & & $\begin{array}{c}+10 \sim-35^{\circ} \mathrm{C}, \\
2 \text { 回 }\end{array}$ & $x$ & -39.4 & -37.4 & - & -38.4 \\
\hline $\bar{\lambda}$ & 35 & & & & & & & & & & & $\begin{array}{c}-20 \sim-35^{\circ} \mathrm{C}, \\
6 \text { 回 }\end{array}$ & $x$ & -36.7 & -40.7 & - & -38.7 \\
\hline & 36 & & & & & & & & & & & $\begin{array}{c}-20 \sim-35^{\circ} \mathrm{C}, \\
11 \text { 回 }\end{array}$ & $x$ & -34.5 & -36.6 & - & -35.6 \\
\hline & 37 & & & & & & & & & & 無 & $\begin{array}{c}0 \sim-25^{\circ} \mathrm{C}, \\
11 \text { 回 }\end{array}$ & $\mathrm{O}$ & - & - & - & - \\
\hline & 38 & & & & & & & & & & & $\begin{array}{c}-10 \sim-20^{\circ} \mathrm{C}, \\
11 \text { 回 }\end{array}$ & 0 & - & - & - & - \\
\hline & 39 & & & & & & & & & & & $\begin{array}{c}-10 \sim-25^{\circ} \mathrm{C}, \\
11 \text { 回 }\end{array}$ & O & - & - & - & - \\
\hline
\end{tabular}


ていた，粗骨材が破壊した場合には界面で破壊した場合 に比べて破壊面の長さが短くなるため，貫通ひび割れの 発生も脆性的に生じていたものと推察された。

(a)図に示す材料・配合要因に関するシリーズ I 試験の 貫通ひび割れ発生温度をみると, アスファルトの種類を 変えた場合に貫通ひび割れ発生温度は-36.0〜 -61.2 ${ }^{\circ} \mathrm{C}$ 範 囲にあり, 最大 $25^{\circ} \mathrm{C}$ 程度の差があった. これに対して, アスファルト量や骨材粒度, 空隙率, 綫維の有無の要因 は-37.9 $-40.2^{\circ} \mathrm{C}$ の範囲で $2^{\circ} \mathrm{C}$ 程度の差であり, 今回の実 験の範囲ではアスファルトの種類を変えた場合に比較す ると影響は小さい結果であった。

(b)図の拘束度や温度低下速度に関するシリーズエ試 験より，アスファルト混合物に対する拘束度が大きい場 合, 貫通ひび割れ発生温度が $3.5^{\circ} \mathrm{C}$ (No.16 と 17 の差) や約 5 7C (No.18〜20 と No.21〜23 の差) 高くなって いることが分かる．また，温度低下速度が速くなった場 合に, 貫通ひび割れ発生温度が高くなっているが（1.4 $\left.\sim 3.5^{\circ} \mathrm{C}\right)$ ，その程度は僅かであることが分かる．これ らの結果から，アスファルト混合物は拘束度によりひび 割れ発生温度が異なり，拘束度が大きい場合に高い温度 でひび割れが発生すると考えられた。 また，この程度の 温度低下速度の美は貫通ひび割れの発生温度にほとんど
影響しないと判断された。

(c)図の持続温度と時間に関するシリーズ而試験から， 温度が低く持続時間が長い時に貫通ひび割れ発生温度が 4 5 $5^{\circ} \mathrm{C}$ と少し高くなり，(d)図から同じ温度間の繰返しで も回数が多くなるとひび割れ発生温度が $3 \sim 4{ }^{\circ} \mathrm{C}$ 高くな っているのが分かる.

今回の試験と温度条件がほぼ同じ既往の研究（試験開 始温度 $+10^{\circ} \mathrm{C}$, 温度低下速度 $-12^{\circ} \mathrm{C} / \mathrm{h}$ )にお打針入度 86 のアスファルトを用いた直方体で，道路用のアスファル 卜混合物を対象とした両端固定の試験における貫通ひび 割れ発生温度は-31.0 ${ }^{\circ} \mathrm{C} \sim-33.4^{\circ} \mathrm{C}$ と報告されており $\left.33,4,10\right)$, 今回の結果 (ストレートアスファルト 80/100 で平均$\left.38.7^{\circ} \mathrm{C}\right)$ の方が $5 \sim 8^{\circ} \mathrm{C}$ 程度低いひび割れ発生温度であっ た.この理由として, 今回のリング状の供試体の方が直 方体の供試体の両端固定に比べてより応力集中の程度が 少ないことや，水工用アスファルト混合物の方が道路用 に比べて伸び能力に優れることなどが考えられたが，詳 細は不明である。

また，それらの報告によれば，貫通ひび割れ発生温度 はアスファルトの感温性に大きく影響される, 空隙率 2.3〜 5.4\%の範囲では空隙率が大きいほど高い,アスファ ルト量 $5.3 \sim 6.8 \%$ ではあまり影響を受けない, 骨材粒度

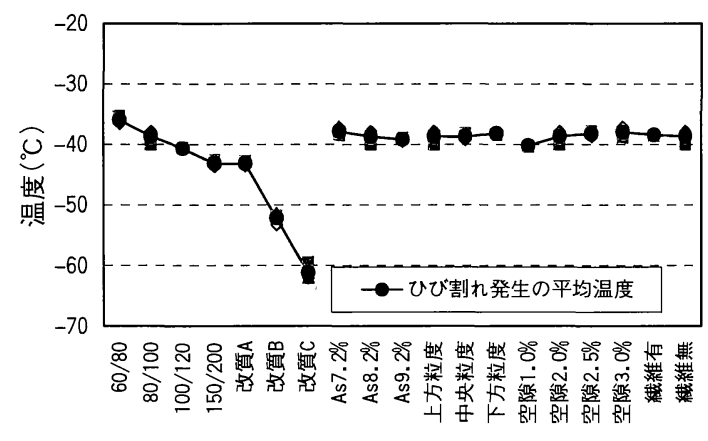

（a）シリーズI結果

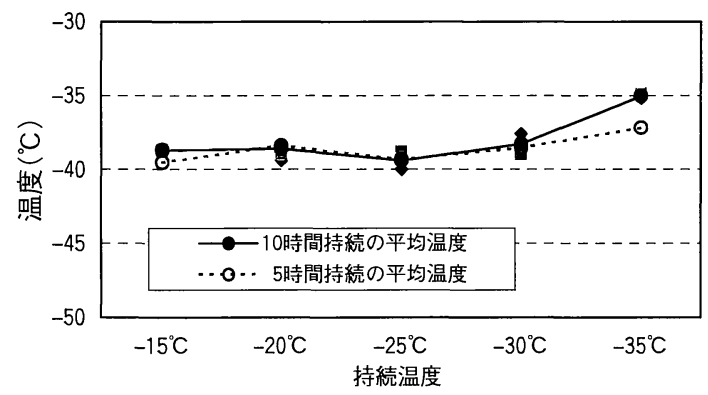

（c）シリーズIII 一定温度持続

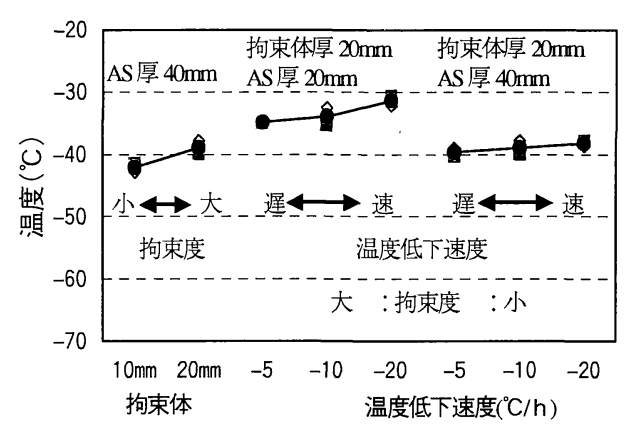

（b）シリーズ【結果

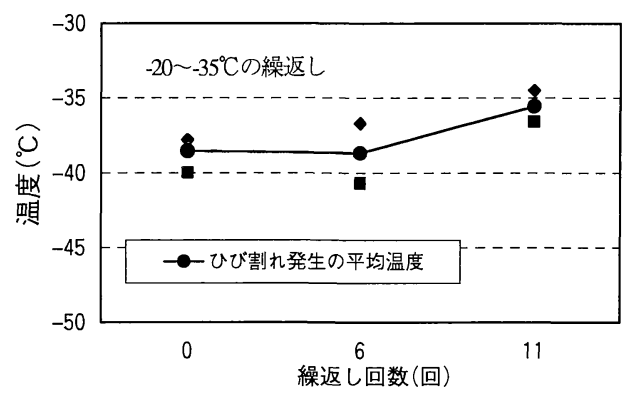

（d）シリーズII 温度繰返し

図一3 貫通ひび割れ発生温度(ひずみゲージによる検知) 


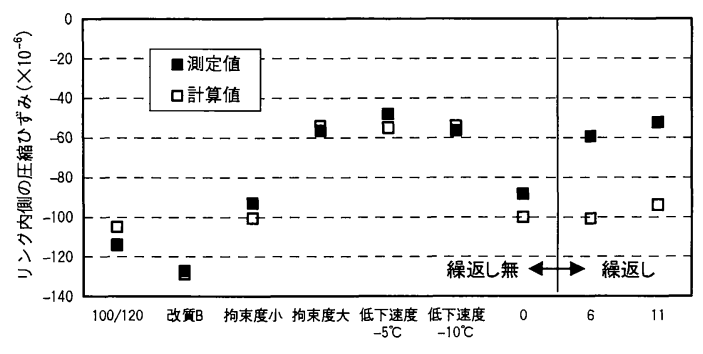

(a)拘束体内側の圧縮ひずみ

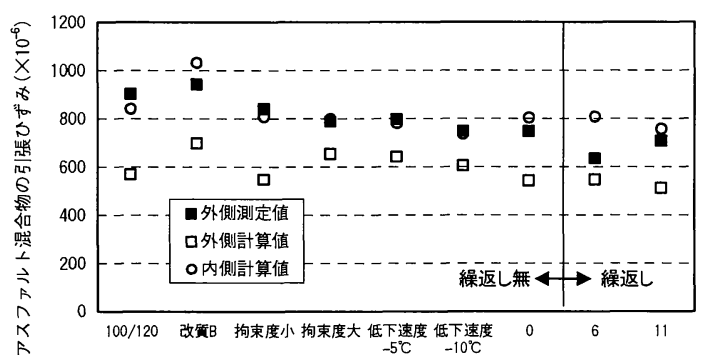

(b)アスファルト混合物の引張ひずみ

\section{図一4＼cjkstart貫通ひび割れ発生時のひずみ}

や温度低下速度-3〜 30대 $\mathrm{h}$ の影響を受けない，貫通ひび 割れ発生温度に近い温度の繰返しは破壊することがある， 温度の繰返しは熱疲労現象が表われて高い温度で破壊す る，などが報告されている3).

既往の研究に今回の実験結果を加えて総合的に判断す ると, 低温ひび割れ抵抗性を向上させるには，アスファ ルトの種類を変えることが極めて効果的であることが分 かった．また，他の内的及び外的要因の影響はアスファ ルト種類の影響に比べて小さいが，同一配合でも拘束度， 温度低下速度, 温度履歴により貫通ひび割れ発生温度が 高くなることが分かった。

このことから，実構造物におけるひび割れ発生温度を 検討する場合には拘束条件を考慮する必要があること， 急激な温度低下やある温度以下の繰返しを受けた場合に は，温度疲労の蓄積によって通常よりも高い温度でひび 割れが発生する可能性があると言うことができる.

\section{(2)ひび割れ発生時のひずみ}

供試体の温度低下に伴って, 拘束体の円周方向にはア スファルト混合物の温度収縮が拘束されることによって 圧縮ひずみが発生する。これに対して，アスファルト混 合物の円周方向には拘束体が元の長さに戻ろうとするこ とに伴う引張ひずみが発生する。 アスファルト混合物に 作用している引張ひずみは拘束体の存在によってアスフ アルト混合物が自由に収縮できないことにより発生する
ひずみであり，このひずみはアスファルト混合物に貫通 ひび割れが発生した際に開放される。

図一4に，ひび割れ発生直前の拘束体内側の圧縮ひず みとアスファルト混合物外側の弓張ひずみの測定值の代 表例を示す．また，同図中には二重円筒管の焼ばめの理 論另により弾性解析で求めた応力と弾性係数から算定し た弾性ひずみの計算值も示している．焼ばめは，外筒の 内径を内筒の外径より直径を少しだけ小さくしておき， 外筒を加熱して膨張したところへ内筒をはめて冷却して 固定し，外筒が収縮することによって内筒を圧縮状態に するものであり，リング拘束供試体を用いた低温ひび割 れ試験のアスファルト混合物（外筒に相当）と拘束体 （内筒に相当）の応力状態に同様なものである.

焼ばめの理論ではリング拘束供試体のアスファルト混 合物内側, 拘束体外壁の半径方向の変位はそれぞれ式 (1)，(2)で表せる.

$$
\left(u_{A}\right)_{r=b}=\frac{b P}{E_{A}}\left(\frac{b^{2}+c^{2}}{c^{2}-b^{2}}+\mu_{A}\right)
$$

$$
\left(u_{I}\right)_{r=b}=-\frac{b P}{E_{I}}\left(\frac{a^{2}+b^{2}}{b^{2}-a^{2}}+\mu_{I}\right)
$$

$$
\left(u_{A}\right)_{r=b}-\left(u_{I}\right)_{r=b}=\delta
$$

ここに, $\left(u_{A}\right)_{r=b}$ : アスファルト内側の半径方向変位

$\left(u_{I}\right)_{r=b}$ : 拘束体外側の半径方向変位

$P$ : 接触圧（アスファルト混合物に作用す る内圧=拘束体に作用する外圧)

$a:$ 拘束体の内側の半径

$b$ : 拘束体の外側の半径, アスファルト混 合物の内側の半径

$c$ :アスファルト混合物の外側の半径

$\mu_{A}, \mu_{I}$ : アスファルト混合物, 拘束体 のポアソン比

$E_{A}, E_{I}$ : アスファルト混合物, 拘束体 の弾性係数

$\delta:$ アスファルト混合物と拘束体の半 径差 $=\left(\alpha_{A}-\alpha_{I}\right) b \times \Delta T$ $\alpha_{A}, \alpha_{I}$ : アスファルト混合物, 拘束体 の線膨張係数

$\Delta T:$ 温度変化量 $\left({ }^{\circ} \mathrm{C}\right)$ 
式(1)と式(2)を式(3)に代入して $P$ を求め, 式(4)，(5)を 用いてアスファルト混合物の円周方向の応力 $\left(\sigma_{A t}\right)$, 拘束体の円周方向の応力 $\left(\sigma_{I t}\right)$ を算出した. ここで, $r$ は円筒の中心からの距離である. 同式より, アスファ ルト混合物の円周方向の引張応力, 拘束体の円周方向の 圧縮応力ともに, 最も内縁側で ( $r$ 最小の場合) で最大 值を示すことが分かる.

$$
\begin{gathered}
\sigma_{A t}=\frac{b^{2} P}{c^{2}-b^{2}}\left(1+\frac{c^{2}}{r^{2}}\right) \\
\sigma_{I t}=\frac{b^{2} P}{b^{2}-a^{2}}\left(1+\frac{a^{2}}{r^{2}}\right)
\end{gathered}
$$

さらに，アスファルト混合物を弾性体と仮定した時の 各部位のひずみを表一6に示す物性值を用いて, 式(6), (7)より算定した．なお，アスファルト混合物の弾性 倸数は別途実施したインダイレクトテンション試験の実 験值を参考にして決定した.

$$
\begin{aligned}
& \varepsilon_{A}=\sigma_{A t} / E_{A} \\
& \varepsilon_{I}=\sigma_{I t} / E_{I}
\end{aligned}
$$

図一4(a)から，拘束体内側の圧縮ひずみはアスファル 卜種類, 拘束度, 温度低下速度を要因としたケースでは 測定值と計算值に大差がないのに対し, 温度繰返しのケ 一スでは測定值が計算值より $40 \times 10^{-6}$ 程度小さいのが分 かる。これは試験時間が長いことから応力緩和や温度疲 労を受け，アスファルト混合物か沟束体を締め付ける力 が徐々に開放されたためと思われた。

また，b)図から，アスファルト外側では全ケースで測 定值が計算值より大きくなっているのが分かる。これは 計算值がアスファルト混合物のクリープや物性值の温度 依存性を考慮していないことが原因と考えられた. 本試 験の場合, 前述のようにアスファルト断面内で最も応力 の大きいのは拘束体との境界部であり, この部位を起点 としてひび割れが発生するので，アスファルト内側のひ ずみがひび割れ発生限界ひずみとなる。

本低温ひび割れ抵抗性試験ではこの部位のひずみを直 接測定できないが，限界ひずみは拘束体の拘束効果はあ るものの, アスファルト外側と同様にクリープや物性值 の違い等の影響からアスファルト内側の計算值と同等ま たは少し大きいと推定され，ひび割れ発生限界ひずみは $800 \times 10^{-6}$ 以上であると考えられた。
表一6 弾性解析に用いた物性值

\begin{tabular}{|c|c|c|c|}
\hline 種類 & $\begin{array}{c}\text { 線膨張係数 } \\
\alpha \\
\left(1 /{ }^{\circ} \mathrm{C}\right)\end{array}$ & $\begin{array}{c}\text { ポアソン } \\
\text { 比 } \\
\mu\end{array}$ & $\begin{array}{c}\text { 弾性係数 } \\
\begin{array}{c}\mathrm{E} \\
\left(\mathrm{N} / \mathrm{mm}^{2}\right)\end{array}\end{array}$ \\
\hline $\begin{array}{c}\text { アスファルト } \\
\text { 混合物 }(\mathrm{A})\end{array}$ & $2.0 \times 10^{-5}$ & 0.25 & $9.8 \times 10^{3}$ \\
\hline 拘束体 $(\mathrm{I})$ & $0.5 \times 10^{-6}$ & 0.25 & $1.4 \times 10^{5}$ \\
\hline
\end{tabular}

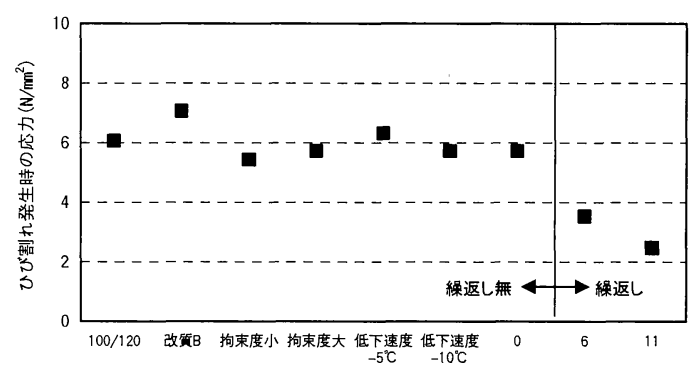

図一5 貫通ひび割れ発生時の応力

低温下の静的破壊試験における破断ひずみは， $-20^{\circ} \mathrm{C}$ の道路用混合物で $100 \times 10^{6}$ のオーダー21)，水工用混合物 で 750 1,000× $10^{6}$ との報告があり ${ }^{22}$ ，戴荷速度の影響 はあるものの, 今回の試験結果のオーダーとほぼ一致し ていることが明らかになった。

\section{（3）ひび割れ発生時の応力}

図一5に，貫通ひび割れ発生時にアスファルト混合物 に作用している平均応力の算定例を示す。ここで，平均 応力はアスファルト混合物と拘束体の力の釣合いと，拘 束体に作用していた圧縮力は貫通ひび割れ発生時に開放 されたひずみ（戻りひずみ）に比例するとの考えから， 式(8)によって求めた.

$$
\sigma_{A}=\frac{\varepsilon_{I I} \times E_{I} \times A_{I}}{A_{A}}
$$

$$
\begin{gathered}
\text { ここに, } \sigma_{A}: \text { アスファルト混合物に作用して平均引 } \\
\text { 張応力 }\left(\mathrm{N}^{2} \mathrm{~mm}^{2}\right) \\
\varepsilon_{I I}: \text { 貫通ひび割れ発生時の拘束体の戻りひ } \\
\text { ずみ }(\text { 測定值 }) \\
A_{A}, A_{I}: \text { アスファルト混合物, 拘束体の断 } \\
\text { 面積 }\left(\mathrm{mm}^{2}\right)
\end{gathered}
$$

図一5より, 繰返しのない実験ケースの貫通ひび割れ 発生時の応力は約 $6 \mathrm{~N} / \mathrm{mm}^{2}$ であり, 繰返しのケースでは $3 \mathrm{~N} / \mathrm{mm}^{2}$ 程度であることが分かる. 繰返しのケースにお 
いても全断面が貫通ひび割れ発生直前まで健全であると して, 原断面積で除して応力を求めているため, 繰返し のないケースに比べて約50\%の応力で破壊しているが, 実際には温度疲労により有効な断面積が減少しており， 低い応力で破壞しているのではないと考えられた。

$-20^{\circ} \mathrm{C}$ 以下の破壊強度試験によるアスファルト混合物 の圧裂強度は5～6 $\mathrm{N} / \mathrm{mm}^{2}$ との報告があり ${ }^{3)}$ ，本試験のひ び割れ発生時の㐫力と大差のない值であった. 本低温ひ び割れ抵抗性試験におけるアスファルト混合物の破断面 では粗骨材が破壊するまでに至っており，静的破壊試験 における破壊状況とほぼ同じであることから，応力が圧 裂強度にほほ等しい值になったものと推察された。また， 繰返し試験による応力の減少率も既往の研究3) と同程度 の值であった。

\section{(4) 変形係数}

図一6に，実測したアスファルト混合物の外側の引張 ひずみと式(8)より算定した平均応力の関係例を示す. アスファルト混合物は温度依存性の材料であり，常温で は粘弾性挙動を示し, 低温では極めて弾性体に近い挙動 を示すことが知られているり。
同図からも応力緩和して引張ひずみに対する応力の増 加量が軽微である領域（曲線部）と，応力の増加量が大 きい弾性挙動を示す領域（直線部）に分けられることが 分かり，転移点と呼ばれる傾きが急激に大きくなる点が 確認できる. 変形係数（傾き）は温度低下に伴い増加し, アスファルトの種類にかかわらず，転移点より低温では ほぼ一定值となっている，本試験ではその時の変形係数 が 15,000〜20,000 $\mathrm{Nmm}^{2}$ 程度であった。ただ，計算に 用いた応力はアスファルト混合物の平均応力であり，ア

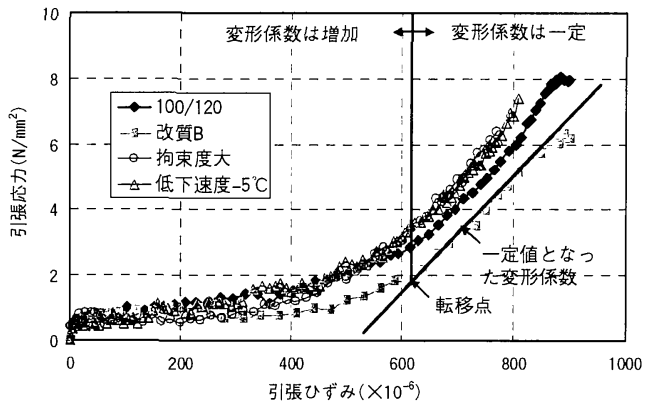

図一6 応力ーひずみ曲線と変形係数
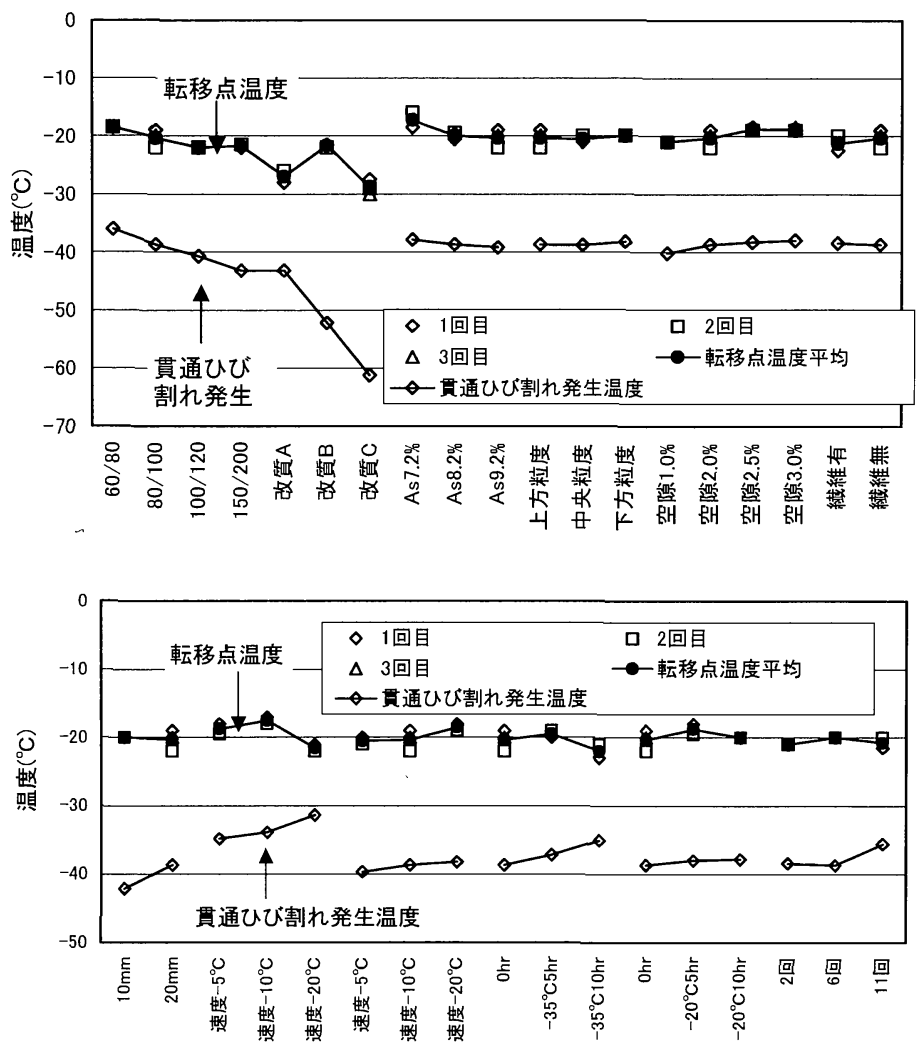

図一7 転移点温度 
表-7 転移点温度, ひび割れ発生温度

\begin{tabular}{|c|c|c|c|c|c|c|c|c|c|c|c|c|c|c|c|}
\hline \multirow[b]{2}{*}{ No. } & \multirow{2}{*}{\multicolumn{2}{|c|}{ Asの種類 }} & \multirow{2}{*}{$\begin{array}{l}\text { 拘束 } \\
\text { 体厚 } \\
(\mathrm{mm}) \\
\end{array}$} & \multirow{2}{*}{$\begin{array}{l}\text { As厚 } \\
(\mathrm{mm})\end{array}$} & \multirow{2}{*}{ 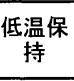 } & \multirow{2}{*}{$\begin{array}{c}\text { 温度繰 } \\
\text { 返 }\end{array}$} & \multicolumn{3}{|c|}{ 転移点温度 $\left({ }^{\circ} \mathrm{C}\right)$} & \multicolumn{3}{|c|}{ 微細ひび割れ発生開始温度 } & \multicolumn{3}{|c|}{ 貫通ひび割れ発生温度 $\left({ }^{\circ} \mathrm{C}\right)$} \\
\hline & & & & & & & 1回目 & 2回目 & 平均 & 㽞目 & 2回目 & 平均 & 1回目 & 2回目 & 平均 \\
\hline \multirow{4}{*}{\begin{tabular}{|l|}
1 \\
2 \\
3 \\
4 \\
5
\end{tabular}} & & $60 / 80$ & \multirow{7}{*}{20} & \multirow{7}{*}{40} & \multirow{7}{*}{ 無 } & \multirow{7}{*}{ 無 } & -21.7 & -18.3 & -20.0 & -22.2 & -22.0 & -22.1 & -37.7 & -37.4 & -37.6 \\
\hline & & $80 / 100$ & & & & & -21.8 & -22.7 & -22.3 & -24.4 & -24.4 & -24.4 & -39.9 & -37.8 & -38.9 \\
\hline & ג & $100 / 120$ & & & & & -26.7 & -22.9 & -24.8 & -24.5 & -24.6 & -24.6 & -42.3 & -39.7 & -41.0 \\
\hline & フルト & $150 / 200$ & & & & & -26.2 & -24.8 & -25.5 & -27.8 & -26.3 & -27.1 & -43.3 & -37.2 & -40.3 \\
\hline \multirow{3}{*}{\multicolumn{2}{|c|}{$\begin{array}{c}\text { 改質ア } \\
\text { スファル } \\
ト\end{array}$}} & $\mathrm{~A}$ & & & & & -26.6 & -22 & -24.3 & -28.7 & -27.4 & -28.1 & -44.7 & -43.6 & -44.2 \\
\hline & & $B$ & & & & & -25 & -24.9 & -25.0 & -30.4 & -27.4 & -28.9 & -50.1 & -46.5 & -48.3 \\
\hline 7 & & C & & & & & -29.4 & -30.3 & -29.9 & -40 & -36 & -38.0 & -63.0 & -58.5 & -60.8 \\
\hline 8 & \multirow{7}{*}{$\begin{array}{l}\text { ストレー } \\
\text { トアス } \\
\text { ファルト }\end{array}$} & \multirow{2}{*}{$80 / 100$} & 10 & 40 & 無 & \multirow{4}{*}{ 無 } & -23.2 & -23.6 & -23.4 & -25.4 & -24.6 & -25.0 & -40.1 & -41.3 & -40.7 \\
\hline 9 & & & 20 & 20 & 铔 & & -21.3 & -23.6 & -22.5 & -24.7 & -26.7 & -25.7 & -34.7 & -37.0 & -35.9 \\
\hline 10 & & \multirow{5}{*}{ " } & \multirow{5}{*}{20} & \multirow{5}{*}{40} & \multirow{2}{*}{$\begin{array}{l}-20^{\circ} \mathrm{C} \\
10 \mathrm{hr} \\
-35^{\circ} \mathrm{C} \\
10 \mathrm{hr} \\
\end{array}$} & & -20.8 & -20.1 & -20.5 & -27.9 & -27 & -27.5 & -36.6 & -39.6 & -38.1 \\
\hline 11 & & & & & & & -21.8 & -23.5 & -22.7 & -25.6 & -25.3 & -25.5 & -35.9 & -35.8 & -35.9 \\
\hline 12 & & & & & \multirow{3}{*}{ 無 } & $\begin{array}{c}0 \sim- \\
25^{\circ} \mathrm{C}, \\
11 \text { 回 }\end{array}$ & -23.4 & -22.1 & -22.8 & -22.5 & -24.9 & -23.7 & -39.3 & -39.8 & -39.6 \\
\hline 13 & & & & & & $\begin{array}{c}-10 \sim- \\
20^{\circ} \mathrm{C}, \\
11 \text { 回 }\end{array}$ & -21.6 & -23.3 & -22.5 & -26.7 & -26.4 & -26.6 & -34.2 & -38.3 & -36.3 \\
\hline 14 & & & & & & $\begin{array}{c}-10 \sim- \\
25^{\circ} \mathrm{C}, \\
11 \text { 回 }\end{array}$ & -23.5 & -23.6 & -23.6 & -23.7 & -27.3 & -25.5 & -40.0 & -39.6 & -39.8 \\
\hline
\end{tabular}

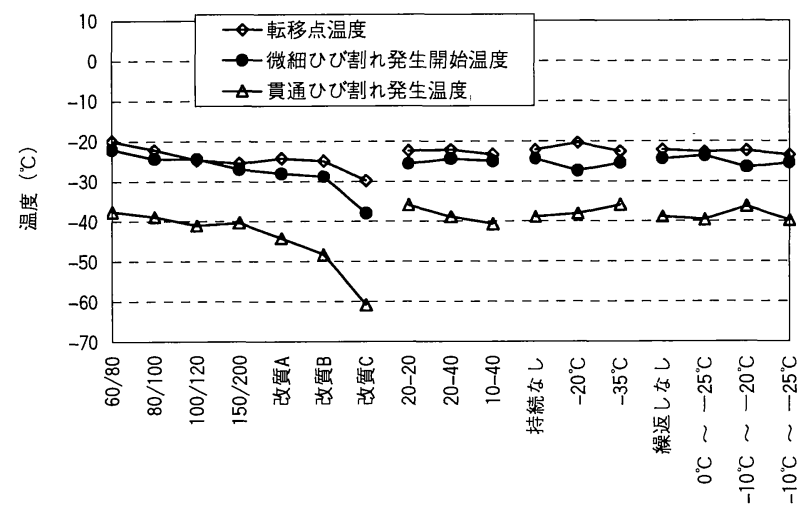

図一8＼cjkstart微細ひび割れ発生開始温度

スファルト外側の応力は平均応力より小さいため, 変形 係数は $15,000 \mathrm{~N} / \mathrm{mm}^{2}$ より小さい可能性がある.

既往の研究においても転移点以後の変形保数はアスフ アルトの針入度によらずほぼ一定になるとしているが, その值は直方体の両端の変位がなく, 完全に拘束してい るとの仮定の下で 7,000 $\mathrm{N} / \mathrm{mm}^{2}$ 程度になるとしている ${ }^{31}$. しかしながら, 実験上完全拘束状態を達成することは難 しく, 変形係数はこの值よりも大きいものと思われた.

\section{(5) 転移点温度}

図一7に，各実験ケースの転移点温度を示す。骨材粒 度や空隙率, 繊維混入の有無, 拘束度, 温度履歴を要因 としたケースの転移点温度はいずれも $-20^{\circ} \mathrm{C}$ 付近であっ た。しかしながら，アスファルトの種類やアスファルト 量によって影響を受け, 特に改質アスファルトA, Cを 用いた場合には温度一応力曲線が低温側に移動し，転移
点温度が低くなる傾向を示した。

この結果より, 転移点温度は拘束度や温度履歴などに は無関係で, 主にアスファルトの種類や配合などから決 まる材料特性であると考えられた.

転移点温度から破壊（貫通ひび割れ発生）温度までの 温度差は既往の研究では約 $10^{\circ} \mathrm{C}$ とれているが3), 本試 験ではストレートアスファルトで10 2 $21^{\circ} \mathrm{C}$, 改質アスフ アルトで16 32ㄷでり, 試験方法が異なることもある が既往のものより温度差が大きい結果であった。

\section{(6)微細ひび割れ発生開始温度}

表一7，図一8に，AE計測を行った実験ケースにおけ る微細ひび割れ発生開始温度を, 転移点温度, 貫通ひび 割れ発生温度とともに示す. 各試験ケースで2供試体ず つ試験を実施したが，2供試体による温度差が小さいた め, 同図は平均値を示している. 


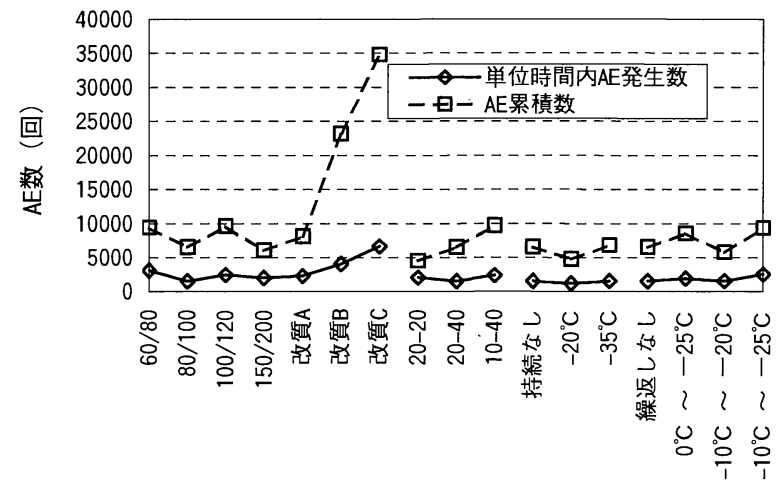

図-9 $\mathrm{AE}$ 発生数

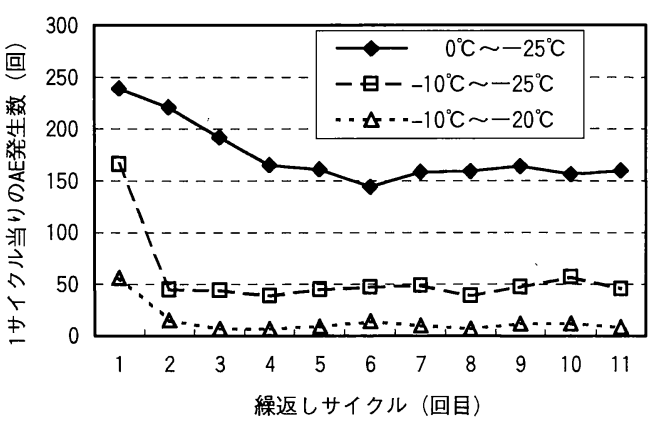

図一10 1サイクル当りの $\mathrm{AE}$ 発生数

同図から，ほほ全試験ケースで高温側から転移点温度， 微細ひび割れ発生開始温度, 貫通ひび割れ発生温度の順 であることが分かる．転移点温度と微細ひび割れ発生開 始温度の温度差は, 改質アスファルトCを用いた場合及 び持続温度-20ํㄷした場合には7 $8^{\circ} \mathrm{C}$ と大きかったが, その他の場合では2 $4^{\circ} \mathrm{C}$ 以下とあまり大きくない結果で あった。 また，微細ひび割れ発生開始温度と貫通ひび割 れ発生温度との温度差はアスファルトの種類や温度履歴 によって異なり $9.8^{\circ} \mathrm{C} \sim 23.7^{\circ} \mathrm{C}$ であた。

アスファルト混合物の転移点温度と微細ひび割れ発生 開始温度は，アスファルトの種類及び配合が同じあれば, 温度履歴や拘束度によらずほぼ同じ温度である結果であ った。したがって，微細ひび割れ発生開始温度も転移点 温度と同様に材料, 配合によって決定される材料特性で あると考えられた，一方，前述の結果と同様に，貫通ひ び割れ発生温度は僅かではあるか拘束度や温度履歴に影 響される結果であった。

高温側から転移点温度, 微細ひび割れ発生開始温度, 貫通ひび割れ発生温度の順であるため, アスファルト混 合物は温度低下に伴い転移点温度で弾性体に近い性状に 変化し, さらに2 $5^{\circ} \mathrm{C}$ 低温になると微細ひび割れが発生
し始めると思われた.これらの各温度はアスファルトの 種類の影響が大きく, 改質アスファルトではストレート アスファルトに比べ各温度とも低くなり, 各温度間の温 度差も大きい結果であった。

微細ひび割れが発生し始めた後は，微細ひび割れの発 生に伴ってひずみが僅かに開放されるものと思われる. しかしながら，応力ーひずみ曲線において応力が小刻み に減少する傾向は認められておらず (図一6参照)，損 傷の程度が軽微で，かつ全体に分散していることから， その影響は応力ーひずみ曲線に顕著に表れなかったもの と推察された。

\section{(7)AE発生数}

図一9に, 単位時間内 $\mathrm{AE}$ 発生数の最大值, 測定開始 $\left(+10^{\circ} \mathrm{C}\right)$ から貫通ひび割れ発生までの $\mathrm{AE}$ 累積数を示す. 同図から, 単位時間内 $\mathrm{AE}$ 発生数, $\mathrm{AE}$ 累積数は, 改質 アスファルト $\mathrm{B} ， \mathrm{C}$ を使用した場合に多いことが分かる. このことは改質アスファルト $\mathrm{B}, \mathrm{C}$ がストレートアスフ アルト等に比べて貫通ひび割れが発生するまでに多くの 微細ひび割れを包含することができることを示している. また，拘束度の小さい試験ケースの方が $\mathrm{AE}$ 累積数が多 い傾向にあることが分かる。

図一10に温度繰返しを行った試験ケースにおける 1 サイクルごとの微細ひび割れ発生数（AE 発生数）を示 す．同図より，上限温度 $0^{\circ} \mathrm{C}$ までの繰返しは上限温度$10^{\circ} \mathrm{C}$ 繰返しに比べ，2 サイクル目以降もあまり $\mathrm{AE}$ 発 生数が減少しないことが分かる.また，いずれのパター ンにおいても 2〜4 サイクル以降で, 1 サイクル当りの $\mathrm{AE}$ 発生数が一定值を示すようになるのが分かる.

一般に，アスファルト混合物は粘弾性体の挙動を示す 温度以上でニーディング作用を受けた場合などでは，微 細な欠临が修復するとされている，今回の実験のような 低温においても，同一サイクルの温度上昇過程で損傷が 
修復し，温度低下過程で同一もしくは他の部位において $\mathrm{AE}$ が発生しているのか，修復することなく温度低下過 程で毎回同数の $\mathrm{AE}$ が発生しているのか，明確には分か らない。しかしながら， $-25^{\circ} \mathrm{C}$ の同一下限温度でも，$10^{\circ} \mathrm{C}$ までの温度上昇に比べて， $0^{\circ} \mathrm{C}$ まで温度上昇したケ 一スの方が $\mathrm{AE}$ 発生数が多くなっていることを考えると, $0^{\circ} \mathrm{C}$ 付近まで温度上昇することによって修復する損傷の 数が多くなっているとも推察された。

\section{5．微細ひび割れ発生に関する検討}

\section{(1)概要}

ひび割れの発生に関係する応力は，供試体断面内の温 度差や骨材とアスファルトの線膨張係数の違いにより発 生する内部拘束応力と，外部の拘束体により拘束される ことで発生する外部拘束応力に大別できる。 これらの応 力によるひび割れ発生を検討するために，アスファルト 単体，アスファルトモルタル，アスファルト混合物につ いて拘束度を变えて実験を行った，さらに内部拘束の影 響を見るために拘束体を取り除いた供試体も試験の対象 とした。

表一8に実験ケースを示す，同表のうち，供試体の内

表一8 実験ケース

\begin{tabular}{|c|c|c|}
\hline \multirow[b]{2}{*}{$\begin{array}{c}\text { 被拘束体の種 } \\
\text { 類 }\end{array}$} & \multicolumn{2}{|c|}{ 拘束状態 } \\
\hline & $\begin{array}{c}\text { 被拘束体厚 } \\
(\mathrm{mm})\end{array}$ & $\begin{array}{c}\text { 拘束体厚 } \\
(\mathrm{mm})\end{array}$ \\
\hline \multirow{4}{*}{$\begin{array}{c}\text { アスファルト混 } \\
\text { 合物 }\end{array}$} & \multirow{3}{*}{40} & なし \\
\hline & & 10 \\
\hline & & 20 \\
\hline & 20 & 20 \\
\hline \multirow{2}{*}{$\begin{array}{c}\text { アスファルトモ } \\
\text { ルタル }\end{array}$} & \multirow{2}{*}{40} & なし \\
\hline & & 20 \\
\hline \multirow{2}{*}{$\begin{array}{c}\text { アスファルト単 } \\
\text { 体 }\end{array}$} & \multirow{2}{*}{40} & なし \\
\hline & & 20 \\
\hline
\end{tabular}

外部の温度差に起因する内部拘束応力の影響は, 供試体 の断面中央の墚さ方向に $1 \mathrm{~cm}$ 間隔で熱電対（芯線径約 $0.3 \mathrm{~mm}$ ，精度 $0.1^{\circ} \mathrm{C}$, 測定点計 3 点）を入れて供試体断面 内の温度差を測定することで検討した，骨材とアスファ ルトの線膨張係数の違いによるひび割れについては，骨 材の最大寸法の異なるアスファルト混合物とアスファル トモルタル，アスファルト単体による拘束体のない供試 体，などの試験結果を比較することで検討した．また， 外部拘束応力による微細ひび割れの発生状況は拘束体の 有無と拘束度を変えた供試体により検討した。

全ての試験ケースでアスファルトはストレートアスフ アルト80/100を使用し，温度低下速度は-10 $\mathrm{C} / \mathrm{h}$ で一定と し，同一ケースの供試体数は 2 体とした。

\section{(2)内部拘束応力による微細ひび割れ}

アスファルト混合物の厚さ $40 \mathrm{~mm}$ の表面から $10 ， 20$, $30 \mathrm{~mm}$ の部位の温度を熱電対によって測定した結果，ア スファルト混合物の表面に塗布した樹脂コーティングの 影響は認められず，また，供試体と水槽内の温度差はほ

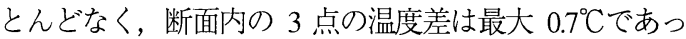
た。このことから， $-10^{\circ} \mathrm{C} / \mathrm{h}$ 程度の温度低下速度では断 面内外部の温度差による内部拘束応力はほとんど発生し ないものと考えられた。

図一11に，拘束体を取り除いた供試体（以下自由収縮 供試体）の単位時間内AE発生数を示す。アスファルト 混合物では微細ひび割れ発生開始温度が- $25^{\circ} \mathrm{C}$ 付近，ア スファルトモルタルが- $32^{\circ} \mathrm{C}$ 付近であったが，アスファ ルト単体ではAEの発生は認められず，微細ひび割れ発 生温度も検知できなかった，自由収縮供試体には拘束体 がなく外部拘束応力が作用しないが，骨材を有する配合

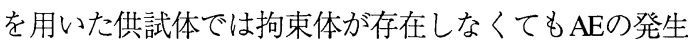
が認められる結果であった。

したがって，骨材とアスファルトとの線膨張係数の違 いに起因して，アスファルトの温度収縮を骨材が拘束す

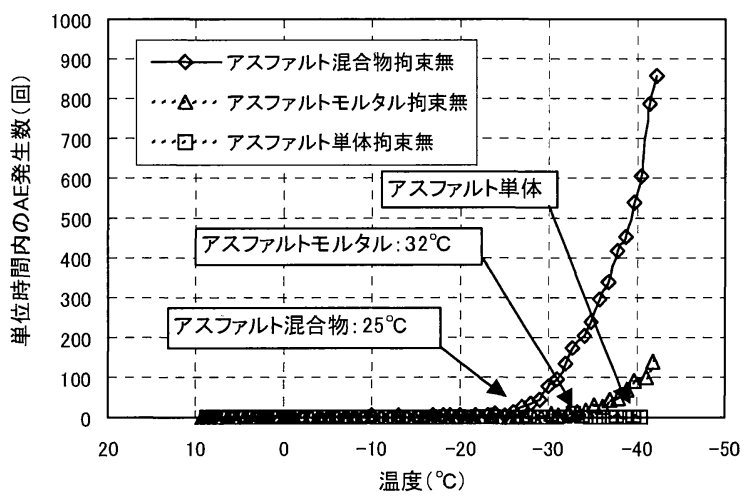

図一11 自由収縮供試体の $\mathrm{AE}$ 発生数 


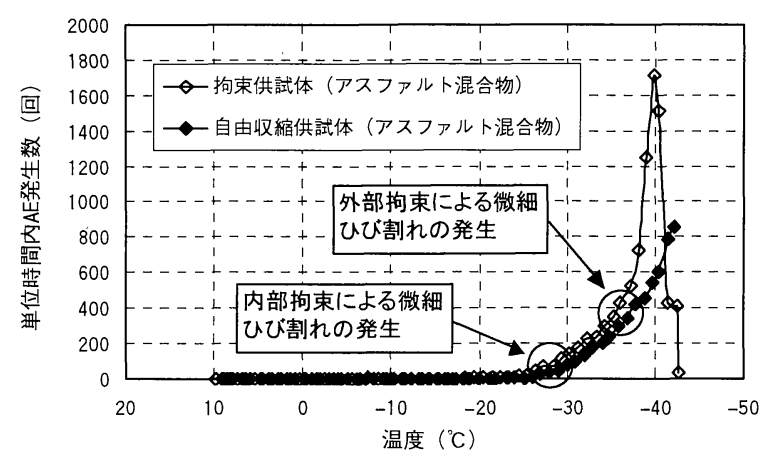

(a)アスファルト混合物

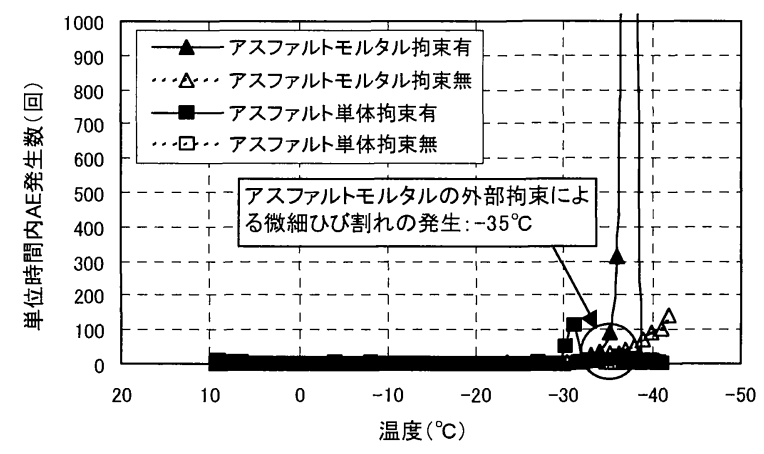

(b)アスファルトモルタル，アスファルト単体

図一12 拘束体の有無による $\mathrm{AE}$ 発生数

る内部拘束応力により， AEが発生したものと考えられ た.すなわち, 粗骨材を含むアスファルト混合物では, 粗骨材の線膨張係数が約 $8 \times 10^{-6} \%^{\circ} \mathrm{C}$ とアスファルトの線 膨張係数が約 $590 \times 10^{6} \%^{\circ} \mathrm{C}$ であことの違いで- $25^{\circ} \mathrm{C}$ から， 細骨材のみ含まれるアスファルトモルタルでは $-32^{\circ} \mathrm{C}$ ら内部拘束応力による微細ひび割れが発生し始めると推 察された. アスファルトモルタルの方が微細ひび割れ発 生開始温度が低い理由としては，細骨材とアスファルト の線膨張係数の違いのほか, 粗骨材と細骨材の拘束度の 違いと思われた。

$\mathrm{AE}$ 発生開始温度は内部拘束応力による微細ひび割れ 発生開始温度であると言うことができる. なお，全ての 自由収縮供試体において断面を貫通するひび割れの発生 は認められなかった.

\section{(3)外部拘束応力による微細ひび割れ}

図一12(a)に，アスファルト混合物を対象とした拘束 体の有無による $\mathrm{AE}$ 発生数を対比して示す. 外部拘束応 力による微細ひび割れは自由収縮供試体と拘束体のある 供試体 (以下拘束供試体) に差か現れる時から発生し始 めていると思われる。自由収縮供試体と拘束供試体の
$\mathrm{AE}$ 発生数を比較すると, 同図に示されるように $-35^{\circ} \mathrm{C}<$ らいまでは両者は同様な発生傾向であるが， $-35^{\circ} \mathrm{C} よ り$ 低温になると拘束供試体で $\mathrm{AE}$ 発生数が急増しているの が分かる．このことから，アスファル混合物は $-35^{\circ} \mathrm{C}$ 付 近から外部拘束による微細ひび割れが発生し始めると考 えられた。

同様に図一12(b)に，アスファルトモルタル，アスフ アルト単体について示す. アスファルト単体の拘束供試 体では貫通ひび割れが発生する直前のみ $\mathrm{AE}$ 発生数が増 加するが, $\mathrm{AE}$ 発生数はごく僅かでその後直ぐに貫通ひ び割れに進展した. 一方, アスファルトモルタルの拘束 供試体において $\mathrm{AE}$ 発生数が急増する温度はアスファル 卜混合物と同じ- $35^{\circ} \mathrm{C}$ 付近からであった.このことから， アスファルトモルタルでは内部拘束応力が作用して微細 ひび割れが発生した後 2 3ㄷ温度が低下すると, 外部 拘束応力による微細ひび割れが発生すると考えられた。

図一13に，アスファルト混合物を対象として拘束度 （拘束体の肉厚と供試体の厚さ）を变化させた実験ケー スにおける温度と単位時間内 $\mathrm{AE}$ 発生数の関係を示す。 同図から，拘束度が大きいほどAEが急激に増加して自 由収縮供試体の温度 $-\mathrm{AE}$ 発生数曲線から離れる温度が 


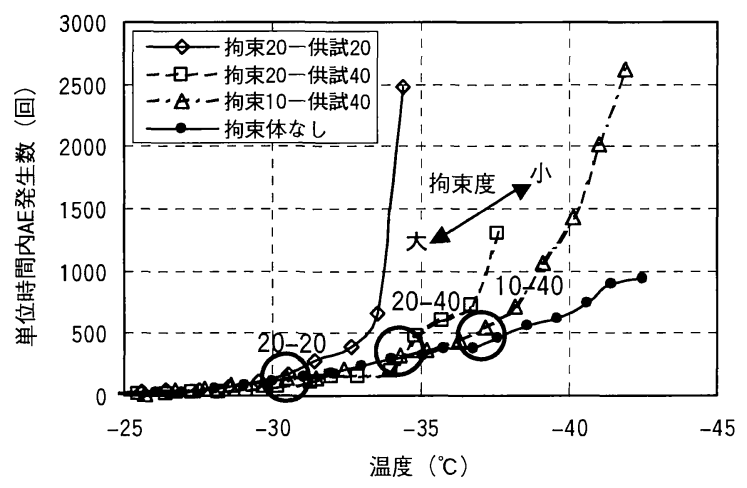

図一13 拘束度の違いによる $\mathrm{AE}$ 発生数 ( $-25^{\circ} \mathrm{C}$ 以降を図示)

表一9 種々のひび割れ発生温度

\begin{tabular}{|c|c|c|c|c|}
\hline \multirow{2}{*}{ 被拘束体 } & \multirow{2}{*}{$\begin{array}{c}\text { 転移点 } \\
\text { 温度 }\end{array}$} & \multicolumn{2}{|c|}{ 微細ひび割れ発生開始温度 } & \multirow{2}{*}{$\begin{array}{c}\text { 貫通ひび割れ発 } \\
\text { 生温度 }\end{array}$} \\
\hline & & 内部拘束 & 外部拘束 & \\
\hline アスファルト混合物 & $-22^{\circ} \mathrm{C}$ & $-24^{\circ} \mathrm{C}$ & \multirow{3}{*}{$\begin{array}{l}\text { 内部拘束による } \\
\text { 微細ひび割れ発 } \\
\text { 生開始温度より } \\
\text { 低温 (拘束度に } \\
\text { より変化) }\end{array}$} & \multirow{3}{*}{$\begin{array}{l}\text { 外部拘束による } \\
\text { 微細ひび割れ発 } \\
\text { 生開始温度より } \\
\text { 低温(拘束度に } \\
\text { より変化) }\end{array}$} \\
\hline $\begin{array}{c}\text { アスファルト混合物 } \\
\text { (改質C) }\end{array}$ & $-30^{\circ} \mathrm{C}$ & $-38^{\circ} \mathrm{C}$ & & \\
\hline $\begin{array}{l}\text { アスファルトモルタル } \\
\text { (ストレートアスフルト80/100) }\end{array}$ & $-21^{\circ} \mathrm{C}$ & $-32^{\circ} \mathrm{C}$ & & \\
\hline
\end{tabular}

高くなっているのが分かる. すなわち, この温度は外部 拘束応力によって微細ひび割れの発生が開始される温度 と思われ，拘束度が大きいほど高温側から外部拘束応力 による微細ひび割れが発生し始めると解釈することがで きる。

また，前述の図一8では，微細ひび割れの発生温度は 拘束度の影響を受けないことを示したが，これは外部拘 束応力よりも高温側で内部拘束応力による微細ひび割れ が拘束体の拘束度にかかわらずに発生しているためと考 えられた。

\section{6. アスファルト混合物の低温ひび割れ抵抗} 性

本実験を通して，アスファルト混合物が低温下に曝さ れる場合，温度低下過程でアスファルト材料自身の物性 変化が生じ，さらに温度降下した場合には骨材とアスフ ァルトの線膨張係数の差や断面内外部の温度差に起因す る内部拘束応力や，外周部の拘束体に起因する外部拘束 応力によって, アスファルト混合物内部に微細ひび割れ が発生し始め，さらに低温になった場合には部材を貫通 するひび割れが発生するものと考えられた。

また，内部に微細ひび割れが発生し，このひび割れが 修復されずに内部欠陥が形成された後は温度疲労が生じ， 健全な部材よりも高温側でアスファルト混合物の破壊が
生じる可能性があると考えられた。

したがって，アスファルト混合物を極低温下の表面遮 水壁に適用する場合，アスファルト混合物の温度か洏移 点温度や内部拘束応力による微細ひび割れ発生開始温度 以下にならなければ，アスファルト混合物に温度応力に よるひび割れが発生することはない.しかしながら，環 境温度が微細ひび割れ発生開始温度より低く, 内部拘束 応力による微細ひび割れの発生が開始した場合は，温度 疲労による影響を受けるため, 室内実験と実構造物の拘 束度の対比による検討や，拘束体を含めた温度応力解析 などにより，構造物の安全性を照査する必要があると結 論付けられる。

表一9に, 本研究より得られた種々のひび割れ発生温 度をまとめて示す. 実際の構造物においては, 外気温の 予測を統計や確率を用いて行うとともに, アスファルト 混合物の供用中の材料劣化などを考慮して，低温ひび割 れ抵抗性を評価することが必要と思われた。

\section{7. 結論}

水工用アスファルト混合物の低温ひび割れ抵抗性を評 価する研究の一環として，リング拘束供試体やAE計測 法を用いた拘束ひび割れ試験を行い，微細ひび割れ発生 温度, 転移点温度, 貫通ひび割れ発生温度やひび割れ発 生時のひずみや応力について検討を行った，その結果， 
以下の結論が得られた。

(1) リング拘束供試体を用いたアスファルト混合物の低 温ひび割れ抵抗性試験により，アスファルト混合物 に貫通ひび割れが発生する温度を測定することが可 能であり, 種々の要因がアスファルト混合物のひび 割れ発生温度に及ぼす影響を相対的に評価すること ができる。また，低温ひび割れ抵抗性試験時にAE を計測することにより，アスファルト混合物に発生 する微細ひび割れを検知することができる。

(2) 既往の研究と同様に, ひび割れ発生温度はアスファ ルトの種類による影響が極めて大きい. また，アス ファルト混合物の温度収縮に対する拘束の程度や温 度低下速度, 温度の繰返し条件もひび割れ発生温度 に影響することが確認された。

（3）アスファルト混合物の変形係数が急激に大きくなり, 応力緩和できなくなる転移点温度は, 温度低下速度 や拘束度の影響は受けず，材料自身の性質によって 決まる。

(4) 転移点以後のアスファルト混合物の変形係数は, 材 料配合条件や拘束条件，温度履歴によらず,ほぼ $15,000 \sim 20,000 \mathrm{~N} / \mathrm{mm}^{2}$ である.

（5）貫通ひび割れ発生時にアスファルト混合物に作用し ている応力は $\mathrm{N} / \mathrm{mm}^{2}$ 程度であり, 圧裂強度の5〜 $\mathrm{N} / \mathrm{mm}^{2}$ と同等の值であった．たたし，ある温度以 下の繰返し履歴を受けた場合には, 見かけ上 $3 \mathrm{~N} / \mathrm{mm}^{2}$ 程度で貫通ひび割れが発生した。

(6) アスファルト混合物の微細ひび割れ発生開始温度は, 拘束度や温度履歴の影響を受けず，アスファルトが 骨材によって拘束されることによって微細ひび割れ が発生し始める温度である。

(7) アスファルト混合物が低温に曝される過程では転移 点温度, 微細ひび割れ発生温度, 貫通ひび割れ発生 温度の順に現れ，アスファルト混合物か弾性材料と なる転移点温度より低温側に $2 \sim 8^{\circ} \mathrm{C}$ 低下した時点で， アスファルトの温度収縮が骨材に拘束されて微細ひ び割れが発生しはじめ, その後, 拘束体の外部拘束 によって部材を貫通するひび割れに進展する.

（8）アスファルト混合物は微細ひび割れ発生温度より高 い温度の範囲では, 温度収縮による内部欠陥の蓄積 がないため, 温度疲労現象が生じない.したがって， 実構造物のアスファルト混合物が置かれる環境温度 が微細ひび割れ発生温度より常に高い場合には，温 度応力ひび割れは発生しない.しかしながら, 環境 温度が微細ひび割れ発生温度より低い場合には, 温 度ひび割れの発生に関する照査が必要になる。

(9)改質アスファルトを用いた混合物はストレートアス ファルトに比べて転移点温度, 微細ひび割れ発生温 度が低く，また，微細ひび割れ発生温度から貫通ひ
び割れが発生するまでの温度差が大きい.

謝辞：本リング拘束供試体を用いた低温ひび割れ抵抗 性試験は，菅原照雄北海道大学名誉教授の指導のもとに 具現化したものであり，また，研究の実施に当り種々の 指導を賜りました.ここに深く感謝致します。

\section{参考文献}

1)水工アスファルト研究会編：水工アスファルト, 現場技術者 のための材料・設計・施工，鹿島出版会，1976.

2)重松和男, 楢原健, 内藤匠：アスファルトフェーシング工法 の開発研究（その4）, フィルダム表面アスファルト遮水壁 の温度応力について, 鹿島建設技術研究所年報, 第21号, pp.27-42, 1973.

3)菅原照雄 : アスファルト舗装の温度亀裂発生予測法の開発に 関する研究，昭和61年度科学研究費補助金，1987.3.

4)Sugawara, T. and Kubo, H. : Low temperature cracking of asphalt pavements, Proc. of intermational conference of cold region developement, Vol.3, 1988.

5)天野隆明, 森吉昭博, 鏡慎, 笠原彰彦: アスファルト舗装の 熱応力と変形の粘弾性解析, 土木学会論文集, 第 564 号/V35, pp.23-32, 1997.5.

6塚越徹：SUPERPAVEによるわが国のアスファルトの評価, ASPHALT, Vol39, No.190, pp10-18, 1997.

7)森吉昭博, 徳光克也 : アスファルト単体とアスファルト混合 物の低温性状, 舖装, Vol29, No.2, pp.12-16, 1994.

8)天野隆明, 徳光克也, 小笠原章, 笠原彰彦, 森吉昭博: アス ファルトおよびアスファルト混合物のぜい化点, 石油学会誌, Vol.39, No.5, pp.378-382, 1996.

9)川井久史，杉山智思，山田優：舗装用混合物の曲け試験によ るレオロジー的性質の測定とその結果に基づく温度応力の 推定に関する研究, 建設用原材料, Vol.8, No.1, pp.31-38, 1998.

10)森吉昭博, 藤原正浩 : アスファルト混合物の熱応力挙動に 関する研究, 土木学会論文集, 第396号/V - 9, pp.129-134, 1988.8 .

11)渡部貴裕, 万木正弘, 大野俊夫, 藤澤理 : アスファルト材 料の温度応力評価手法, 鹿島技術研究所年報, 第48号, pp.45 $-50,2000.9$.

12)渡部貴裕, 大野俊夫, 藤澤理, 万木正弘：アスファルト材 料の温度応力評価手法（その2）， $\mathrm{AE}$ 計測による低温ひび割 れの評価, 鹿島技術研究所年報, 第49号, pp.85-90, 2001.9.

13)大野俊夫, 渡部貴裕, 万木正弘：リング拘束による低温ひ び割れ抵抗性試験方法の開発，土木学会第54回年次学術講 演会, V - 205, pp.410-411, 1999.9.

14)大野俊夫, 渡部貴裕, 万木正弘, 藤澤理: 水工用アスファ ルト混合物の低温ひび割れ抵抗性, 土木学会第55回年次学術 
講演会, V - 70, pp.140-141, 2000.9.

15)Wiegrink, K. Marikunte, S. and Shah, S.P. : Shrinkage Cracking of High-Strength Concrete, ACI Materials Journal, pp.409-415, September-october, 1996.

16)重松和男, 楢原健, 内藤匠：フィルダム遮水壁用アスファ ルトコンクリートの破断現象について, 鹿島建設技術研究 所年報，第20号，pp.1-13，1972.

17)(社)土木学会: 舗装工学, p.166, 1995.2.

18)(社)日本コンクリート工学協会：コンクリート技術の要点 2001, p.10, 2001.9.

19)大津政康：アコースティック・エミッションによる非破壊 検査の現状, コンクリート工学, Vol.35, No.12, pp.12-17,
1997.12.

20)大串雅信：材料力学通論, 工学図書, 1966.

21)森吉昭博, 新田登: 脆性領域におけるアスファルト混合物 の破壊に関する研究, 土木学会論文集, 第390号/ $\mathrm{V}-8$, pp.219-224, 1988.2 .

22)吉田隆輝 : 水工用アスファルト混合物の力学性状, 農業土 木学会論文集，No.190，pp.53-59，1997.8.

(2003.2.18受付)

\section{EXPERIMENTAL STUDIES ON CRACKING RESISTANCE OF ASPHALT MIXTURE FOR HYDRAULIC STRUCTURE AT LOW TEMPERATURE}

\section{Toshio OHNO, Takahiro WATANABE and Masahiro YURUGI}

As a part of the sequential study to evaluate the cracking resistance at low temperature of asphalt mixture for hydraulic structures, the ring-type asphalt mixture specimens restrained by an inner steel ring are exposed to low temperature. Influences of material types, mix proportion, degree of restraint and history of temperature upon the temperature on the occurrence of cracks are examined. The corresponding strain and stress of the mixture at the cracking time and the transition temperature at which the mixture changes from viscoelastic stage to elastic stage are discussed. The temperature at which micro cracks occur in the asphalt mixture is measured utilizing the acoustic emission method. 